\title{
The nitrogen requirement of the weanling kitten
}

\author{
BY KATHERINE A. SMALLEY*, QUINTON R. ROGERS, \\ JAMES G. MORRIS AND LOREN L. ESLINGER \\ VM Physiological Sciences, University of California-Davis, Davis, \\ California 95616, USA
}

(Received 16 May 1984 - Accepted 19 November 1984)

1. The nitrogen requirement of the weanling kitten was determined in a series of three experiments. In each experiment, diets were formulated to provide the growing kitten with the essential amino acids at or above the level of requirement. Expt 1 utilized a $4 \times 4$ balanced Latin square design with two groups of kittens (four male and four female). The crystalline L-amino acid diets were presented at four levels of dietary crude protein $(\mathrm{N} \times 6 \cdot 25)$ of $140,160,180$ and $200 \mathrm{~g} / \mathrm{kg}$ diet. The design for Expts 2 and 3 was a $6 \times 6$ balanced Latin square. For each of these experiments, groups of six male and six female kittens were assigned to diets. The six levels of dietary crude protein were $120,140,160,180,200$ and $220 \mathrm{~g} / \mathrm{kg}$ diet; dietary $\mathrm{N}$ was supplied by crystalline L-amino acids for Expt 2 and casein plus a supplementary amino acid mix for Expt 3. Food intake, weight gain and $\mathrm{N}$ retention were determined in each experiment.

2. A sigmoidal model $y=\mathrm{P} 1+\mathrm{P} 2 /\left[1+\mathrm{e}^{(\mathrm{P} 3+\mathrm{P} 4 \cdot x)}\right]$ was fitted to the response of weight gain and $\mathrm{N}$ retention to dietary $\mathrm{N}$. The calculated requirement $(95 \%$ of the upper asymptote, $\mathrm{P} 1+\mathrm{P} 2)$ for these experiments varied from 170 to $230 \mathrm{~g}$ protein $/ \mathrm{kg}$ diet with the majority of these values falling between 180 and $200 \mathrm{~g} \mathrm{protein} / \mathrm{kg}$.

3. On the basis of these three experiments, the kitten's requirement for dietary crude protein is between 180 and $200 \mathrm{~g} / \mathrm{kg}$ diet $(28 \cdot 8-32.0 \mathrm{gN} / \mathrm{kg})$ for purified diets which provide a calculated $21 \mathrm{MJ}$ metabolizable energy $/ \mathrm{kg}$ diet.

The dietary requirement for protein is based on two metabolic demands: (1) the necessity for sufficient quantities of essential amino acids in the proper proportions, (2) the necessity for adequate amounts of nitrogen to provide for the synthesis of non-essential amino acids and other nitrogenous compounds.

Within the last 5 years the essential amino acid requirements for maximal kitten growth have been determined with crystalline L-amino acid diets. Protein requirements of the kitten determined before this information was available may have been inflated due to insufficient amounts of a particular amino acid. In addition, protein requirements determined using animal protein sources may be confounded by the association of the level of protein and palatability of the diet. Based on studies in which either casein or a mixture of fish and liver were used as the protein source (Dickinson \& Scott, 1956; Miller \& Allison, 1958; Jansen et al. 1975), the (US) National Research Council (1978) recommended that 'a protein of a quality equivalent to that derived from unprocessed mammalian, avian or fish muscle should be presented at a level of $28 \%$ of metabolizable energy (ME) in the diet of a growing kitten. This is equivalent to $35 \%$ protein in a diet (dry basis) providing $21 \mathrm{~kJ}(5 \mathrm{kcal}) \mathrm{ME} / \mathrm{g}$ dry matter'. To define the $N$ requirement more precisely we have completed three experiments in which all essential amino acids were supplied in adequate amounts and $\mathrm{N}$ was supplied as individual amino acids or casein. Food intake, weight gain and $\mathrm{N}$ retention have been determined in all three studies with a total of six different dietary protein levels from 120 to $220 \mathrm{~g}$ crude protein $(\mathrm{N} \times 6.25) / \mathrm{kg}$ diet.

* Present address: Department of Home Economics, Box 3470, New Mexico State University, Las Cruces, NM 88003-3470, USA. 


\section{METHODS}

Diets

Diets for the three experiments were formulated to provide adequate amounts of the essential amino acids and a mixture of non-essential amino acids at the lowest crude protein level tested in each experiment (Rogers \& Morris, 1982). Growth rate of rats is greater when the non-essential amino acids have been provided by a combination of amino acids (Rogers et al. 1970) and it has been noted that asparagine may be necessary for maximal growth of kittens (E. M. Kamakawa, J. G. Morris and Q. R. Rogers, unpublished results).

Compositions of the diets at the lowest protein level are given in Tables 1 and 2 . Crystalline L-amino acids were the only source of dietary $N$ in Expts 1 and 2 (Table 3). Four levels of dietary crude protein were used in Expt $1(140,160,180$ and $200 \mathrm{~g} / \mathrm{kg}$ diet $)$ and two additional levels ( 120 and $220 \mathrm{~g} / \mathrm{kg}$ diet) in Expt 2 . The $20 \mathrm{~g} / \mathrm{kg}$ increments of dietary crude protein in both experiments were attained by increasing the proportion of amino acid mix and decreasing starch by an equivalent proportion.

The previously mentioned six levels of dietary protein $(120-220 \mathrm{~g} / \mathrm{kg})$ were used in Expt 3, but as a combination of casein plus supplemental essential amino acids (Table 3). The amount of casein was increased to achieve the $20 \mathrm{~g} / \mathrm{kg}$ increments of dietary protein; the supplemental amino acid mix remained constant $(56.4 \mathrm{~g}$ protein $/ \mathrm{kg}$ diet) for all six levels of dietary protein. Food and water were available ad lib. throughout the study.

\section{Animals}

Specific pathogen-free kittens were weaned and given a $240 \mathrm{~g}$ amino acid $/ \mathrm{kg}$ diet (equivalent to $231.2 \mathrm{~g}$ crude protein $/ \mathrm{kg}$ diet) for 3 weeks before the beginning of each study (Smalley et al. 1983). Following this adjustment period, kittens were selected for the experiments based on a body-weight gain of at least $10 \mathrm{~g} / \mathrm{d}$ and an initial weight of approximately $1 \mathrm{~kg}$. The mean initial weights for Expt 1 were 890 (SE 41) g for female kittens and 850 (SE 21) g for males. For Expts 2 and 3, mean initial weights were somewhat higher: 1322 (SE 51) g and 1249 (SE 47) g for females, and 1084 (SE 65) g and 1237 (SE 21) g for males respectively.

Kittens were randomly assigned to diets for the first period; in subsequent periods, diet assignments were in accordance with a balanced Latin square design (Cochran \& Cox, 1957). Each experiment was composed of two Latin squares, one of female and the other of male kittens. Each period was $10 \mathrm{~d}$ in length. Body-weight and food intake were measured daily throughout each period. Mean daily weight gains for each period were calculated from a least-squares regression of body-weight on time. Urine and faeces of each kitten were collected daily and grouped for analysis into two 5 -d portions for each period. $\mathrm{N}$ determinations were performed on diet, urine and faecal samples by the Kjeldahl procedure (Association of Official Agricultural Chemists, 1975). $\mathrm{N}$ retention was calculated by subtracting urinary and faecal $\mathrm{N}$ from dietary $\mathrm{N}$ intake. Hair loss was ignored in calculating $\mathrm{N}$ retention due to the difficulty of obtaining complete collections. Blood samples for plasma amino acid analysis were obtained from the jugular vein at 10.00-12.00 hours on the 7th day of each period for Expts 2 and 3 and stored at $-81^{\circ}$ until analysed. For analysis, samples were thawed, deproteinized with equivalent volumes of a solution of $60 \mathrm{~g}$ sulphosalicylic acid/1, brought to a $\mathrm{pH}$ of $2 \cdot 2$ with lithium hydroxide solution and analysed on a Beckman Model 121-MB amino acid analyser (Beckman Instruments, Palo Alto). Samples for Expt 3 were analysed for each individual animal. For Expt 2, plasma samples were pooled according to diet for each sex. 
Table 1. Expt 1. Diet composition ( $\mathrm{g} / \mathrm{kg}$ diet)

\begin{tabular}{llc}
\hline \hline & Amino acid mix* & $150 \cdot 0(143 \cdot 1)$ \\
Sodium acetate $\dagger$ & $14 \cdot 9$ \\
Chicken fat & $250 \cdot 0$ \\
Sucrose & $200 \cdot 0$ \\
Starch & $318 \cdot 8$ \\
Mineral mix $\ddagger$ & $40 \cdot 0$ \\
Potassium chloride & $10 \cdot 0$ \\
Vitamin mix§ & $10 \cdot 0$ \\
Choline bitartrate & $6 \cdot 3$ \\
Cellulose\| & $10 \cdot 0$ \\
\hline
\end{tabular}

* For details, see Table 3. Value in parentheses is amount of free base amino acid mix.

$\dagger$ Sodium acetate added in amounts equimolar to the hydrochlorides in the amino acid mix.

For details of composition, see Smalley et al. (1983).

$\S$ Contained $(\mathrm{mg} / \mathrm{kg}$ diet): retinyl palmitate 11 , cholecalciferol 0.05 , DL- $\alpha$-tocopheryl acetate 160 , menadione 15 , thiamin hydrochloride 25 , riboflavin 10 , pyridoxine 10 , nicotinic acid 100 , calcium pantothenate 20 , myoinositol 200 , folic acid 10, cobalamin 0.05, biotin 1, ascorbic acid 200, taurine 200 .

$\|$ Solkafloc (non-nutritive fibre); Brown \& Company, Berlin, New Hampshire. Added at $10 \mathrm{~g} / \mathrm{kg}$ completed diet.

Table 2. Expts 2 and 3. Diet composition $(\mathrm{g} / \mathrm{kg}$ diet $)$

\begin{tabular}{lcc}
\hline & Expt 2 & Expt 3 \\
\hline Amino acid mix & & \\
Casein $\dagger$ & $124 \cdot 5(117 \cdot 8)$ & $56 \cdot 7(52 \cdot 2)$ \\
Sodium acetate $\ddagger$ & $14 \cdot 9$ & $78 \cdot 8$ \\
Turkey fat $\$$ & $250 \cdot 0$ & $10 \cdot 0$ \\
Sucrose & $200 \cdot 0$ & $250 \cdot 0$ \\
Starch $\|$ & $344 \cdot 3$ & $200 \cdot 0$ \\
Mineral mix & $50 \cdot 0$ & $338 \cdot 2$ \\
Vitamin mix & $10 \cdot 0$ & $50 \cdot 0$ \\
Choline bitartrate & $6 \cdot 3$ & $10 \cdot 0$ \\
Cellulose $\dagger \dagger$ & $10 \cdot 0$ & $6 \cdot 3$ \\
\hline
\end{tabular}

* Values in parentheses are free base amino acid mix.

$\uparrow$ Vita-free casein; US Biochemical Corporation, Cleveland, Ohio.

$\$$ Sodium acetate added in amounts equimolar to the hydrochlorides in the amino acid mix.

$\S$ Rendered turkey fat; distributed by Valley Fresh, Turlock, California.

\| Melojel, food grade maize starch; National Starch and Chemical Co., Bridgewater, New Jersey.

7f Contained (g/kg mix): $\mathrm{CaHPO}_{4} 390 \cdot 0, \mathrm{~K}_{2} \mathrm{HPO}_{4} 90 \cdot 0, \mathrm{CaCO}_{3} 110 \cdot 0, \mathrm{MgSO}_{4} 45 \cdot 0, \mathrm{KCl} 200 \cdot 0, \mathrm{NaCl} 140 \cdot 0$, trace mineral mix 25.0. Trace mineral mix contained ( $\mathrm{g} / \mathrm{kg}$ mineral mix): $\mathrm{MnSO}_{4} \cdot \mathrm{H}_{2} \mathrm{O} 3 \cdot 84, \mathrm{ZnSO}_{4} \cdot 7 \mathrm{H}_{2} \mathrm{O} 4 \cdot 45$, $\mathrm{CuSO}_{4} .5 \mathrm{H}_{2} \mathrm{O} \quad 0.80, \quad \mathrm{FeC}_{6} \mathrm{H}_{5} \mathrm{O}_{7} .3 \mathrm{H}_{2} \mathrm{O} \quad 10 \cdot 0, \mathrm{Ca}_{5}\left(\mathrm{IO}_{6}\right)_{2} \quad 0.15, \quad \mathrm{SnCl}_{2} .2 \mathrm{H}_{2} \mathrm{O} \quad 0 \cdot 10, \quad \mathrm{Na}_{2} \mathrm{SeO}_{3} \quad 0.03$, $\left(\mathrm{NH}_{4}\right)_{6} \mathrm{Mo}_{7} \mathrm{O}_{4} \cdot 4 \mathrm{H}_{2} \mathrm{O} 0.04, \mathrm{CrCl}_{3} .6 \mathrm{H}_{2} \mathrm{O} 0 \cdot 26, \mathrm{NiCl}_{2} .6 \mathrm{H}_{2} \mathrm{O} 0 \cdot 30, \mathrm{NaF} 0 \cdot 14, \mathrm{NH}_{4} \mathrm{VO}_{3} \cdot 4 \mathrm{H}_{2} \mathrm{O} 0.02$, carrier ( NaCl) 4.87 .

** Composition of the vitamin mix is the same as previously reported in Table 1 with the exception that taurine was $375 \mathrm{mg} / \mathrm{kg}$ diet.

$\dagger \dagger$ Solkafloc (non-nutritive fibre); Brown \& Company, Berlin, New Hampshire. Added as $10 \mathrm{~g} / \mathrm{kg}$ completed diet.

\section{Statistical treatment}

The balanced Latin square design used for these experiments provides measures of the direct effects that have been corrected for residual effects of the preceding period (Cochran \& Cox, 1957). In each experiment an analysis of variance was performed on male and female kittens both separately and combined for food intake, weight gain and $\mathrm{N}$ retention. Contingent on the indication of a significant direct effect by ANOVA, differences between individual 
Table 3. Amino acid composition of diets $(\mathrm{g} / \mathrm{kg}$ diet $)$

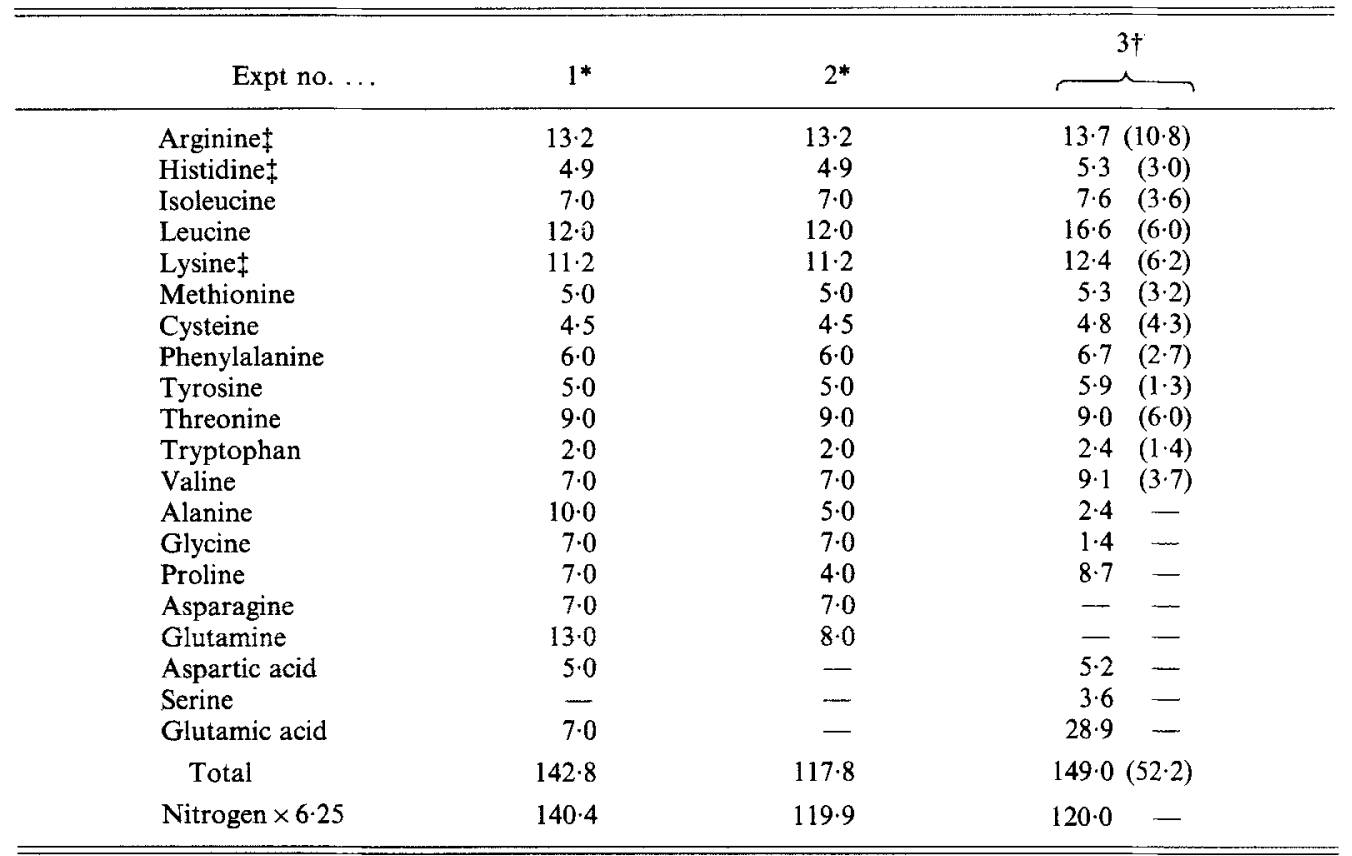

* Composed of crystalline L-amino acids; Ajinomoto USA Inc., Raleigh, North Carolina.

$\dagger$ Composed of $78.8 \mathrm{~g}$ casein $/ \mathrm{kg}$ diet ('Vita-free' casein; US Biochemicals Corporation, Cleveland, Ohio) plus a supplementary L-amino acid mix. Amino acid composition of casein was determined by acid-hydrolysis under $\mathrm{N}_{2}$ and subsequent analysis on an amino acid analyser (Model 121MB; Beckman Instruments, Palo Alto, California). Amounts contributed by the amino acid mix are given in parentheses.

$\ddagger$ In crystalline L-amino acid mixtures, these amino acids were added as arginine hydrochloride, histidine hydrochloride monohydrate and lysine hydrochloride but were calculated here as free base to facilitate comparison between diets.

means were determined with the Student-Newman-Keuls' (SNK) multiple range test (Steel $\&$ Torrie, 1980). The criterion of significance was $P<0.05$ for all statistical analysis.

A sigmoidal response function was fitted to weight gain and $\mathrm{N}$ retention of the following groups: Expt 2, male and combined sexes; Expt 3, male, female and combined sexes. For the function used,

$$
y=\mathrm{P} 1+\mathrm{P} 2 /\left[1+\mathrm{e}^{\left(\mathbf{P} 3+\mathbf{P}_{4} \cdot x\right)}\right],
$$

$y$ is the response (weight gain or $\mathrm{N}$ retention) and $x$ is the level of dietary crude protein (Robbins et al. 1979). The four parameters (P1, P2, P3, P4) were calculated by use of BMDP statistical software package program (PAR) which utilizes a least-squares procedure to estimate parameters of a specified non-linear regression (Ralston, 1981). The adequacy of each model was determined by testing for lack of fit, which entails subdividing the residual sum of squares into pure error SS, and lack of fit SS (Draper \& Smith, 1981). When adequacy was indicated, the overall regression was subsequently tested. The requirement was calculated as $95 \%$ of the upper asymptote $(\mathrm{P} 1+\mathrm{P} 2$; Table 7 , p. 508$)$. 
Table 4. Effect of dietary protein level on food intake $(\mathrm{g} / \mathrm{d})$ for three experiments*

(Values are means of average food intake of each animal over a $10 \mathrm{~d}$ period; no. of kittens given in parentheses)

\begin{tabular}{|c|c|c|c|c|c|c|c|c|c|}
\hline \multirow{2}{*}{$\begin{array}{c}\text { Expt no.... } \\
\text { Dietary } \\
\text { protein equivalent } \\
(\mathrm{g} / \mathrm{kg} \text { diet })\end{array}$} & \multicolumn{3}{|c|}{1} & \multicolumn{3}{|c|}{2} & \multicolumn{3}{|c|}{3} \\
\hline & $\begin{array}{c}0 \\
(4)\end{array}$ & $\begin{array}{c}q \\
(4)\end{array}$ & $\begin{array}{c}a+q \\
(8)\end{array}$ & $\begin{array}{c}0 \\
(6)\end{array}$ & $\begin{array}{c}q \\
(6)\end{array}$ & $\begin{array}{l}a+q \\
(12)\end{array}$ & $\begin{array}{c}3 \\
(6)\end{array}$ & $\begin{array}{c}q \\
(6)\end{array}$ & $\begin{array}{l}0+q \\
(12)\end{array}$ \\
\hline 120 & - & - & - & 53 & 39 & 46 & 50 & $32^{\mathrm{a}}$ & $41^{\mathrm{a}}$ \\
\hline 140 & 45 & 41 & 43 & 54 & 40 & 47 & 55 & $31^{a}$ & $43^{a}$ \\
\hline 160 & 48 & 39 & 44 & 52 & 40 & 46 & 55 & $41^{b}$ & $48^{\mathrm{ab}}$ \\
\hline 180 & 45 & 38 & 42 & 58 & 41 & 50 & 62 & $46^{\mathrm{b}}$ & $54^{b}$ \\
\hline 200 & 44 & 41 & 42 & 54 & 42 & 48 & 56 & $44^{\mathrm{b}}$ & $50^{\mathrm{b}}$ \\
\hline 220 & - & - & - & 54 & 45 & 49 & 60 & $44^{b}$ & $52^{b}$ \\
\hline Pooled SE & $4 \cdot 0$ & 0.9 & $1 \cdot 5$ & 1.9 & 1.8 & $1 \cdot 3$ & $2 \cdot 5$ & $3 \cdot 1$ & $2 \cdot 0$ \\
\hline
\end{tabular}

a, b Means within a column with a different superscript letter were significantly different $(P<0 \cdot 05)$.

* For details of experiments, see p. 502.

Table 5. Effect of dietary protein level on weight gain $(\mathrm{g} / \mathrm{d})$ for three experiments* (Values are means of least squares regression of daily body-weights for each animal over a $10 \mathrm{~d}$ period; no. of kittens given in parentheses)

\begin{tabular}{|c|c|c|c|c|c|c|c|c|c|}
\hline \multirow{2}{*}{$\begin{array}{c}\text { Expt no.... } \\
\text { Dietary } \\
\text { protein equivalent } \\
\text { (g/kg diet) }\end{array}$} & \multicolumn{3}{|c|}{1} & \multicolumn{3}{|c|}{2} & \multicolumn{3}{|c|}{3} \\
\hline & $\begin{array}{c}\hat{3} \\
(4)\end{array}$ & $\begin{array}{c}q \\
(4)\end{array}$ & $\begin{array}{c}\hat{o}+q \\
(8)\end{array}$ & $\begin{array}{l}0 \\
(6)\end{array}$ & $\begin{array}{c}q \\
(6)\end{array}$ & $\begin{array}{c}\delta+q \\
(12)\end{array}$ & $\begin{array}{c}3 \\
\text { (6) }\end{array}$ & $\begin{array}{c}\text { 울 } \\
(6)\end{array}$ & $\begin{array}{l}0+q \\
(12)\end{array}$ \\
\hline 120 & -- & - & - & $10^{\mathrm{a}}$ & $7^{\mathrm{a}}$ & $9^{\mathrm{a}}$ & $8^{\mathrm{a}}$ & $-1^{a}$ & $4^{a}$ \\
\hline 140 & 12 & 8 & $10^{\mathrm{a}}$ & $13^{\mathrm{a}}$ & $8^{a}$ & $10^{\mathrm{a}}$ & $14^{\mathrm{ab}}$ & $0 \cdot 2^{a}$ & $7^{\mathrm{a}}$ \\
\hline 160 & 18 & 11 & $14^{\mathrm{b}}$ & $14^{a}$ & $11^{a b}$ & $12^{\mathrm{a}}$ & $17^{\mathrm{b}}$ & $8^{b}$ & $12^{\mathrm{D}}$ \\
\hline 180 & 18 & 12 & $15^{\mathrm{b}}$ & $24^{b}$ & $14^{\mathrm{ab}}$ & $19^{\mathrm{b}}$ & $27^{\mathrm{c}}$ & $16^{c}$ & $22^{c}$ \\
\hline 200 & 19 & 16 & $18^{\mathrm{b}}$ & $21^{\mathrm{b}}$ & $17^{\mathrm{ab}}$ & $19^{\mathrm{b}}$ & $28^{c}$ & $19^{\mathrm{c}}$ & $24^{\mathrm{c}}$ \\
\hline 220 & - & - & - & $21^{\mathrm{b}}$ & $20^{\mathrm{b}}$ & $21^{b}$ & $32^{\mathrm{c}}$ & $16^{\mathrm{c}}$ & $24^{c}$ \\
\hline Pooled SE & $2 \cdot 8$ & $1 \cdot 7$ & 1.2 & 1.6 & $2 \cdot 5$ & 1.5 & $2 \cdot 4$ & 1.6 & 1.4 \\
\hline
\end{tabular}

a, b, c Means within a column with a different superscript letter were significantly different $(P<0.05)$.

* For details of experiments, see p. 502.

\section{RESULTS}

In both Expts 1 and 2, food intake did not differ in relation to dietary protein level. In Expt 3, food intakes of female and combined sexes were significantly lower on the two lowest dietary protein levels (Table 4).

Analysis of variance indicated a significant effect $(P<0.05)$ of dietary protein level on weight gain for the sexes treated individually and combined for Expts 2 and 3 and for the combined sexes of Expt 1 (Table 5). SNK multiple-range test on values for the combined sexes in Expt 1 indicated that weight gain was significantly lower on $140 \mathrm{~g}$ protein $/ \mathrm{kg}$ diet compared with the three higher protein levels. For the male and combined sexes in Expt 2, and male, female and combined sexes in Expt 3, weight gains were significantly greater at the three highest levels of dietary protein $(180-220 \mathrm{~g} / \mathrm{kg}$ diet) compared with the three lowest levels. Female weight gain in Expt 2 was significantly greater at $220 \mathrm{~g}$ 


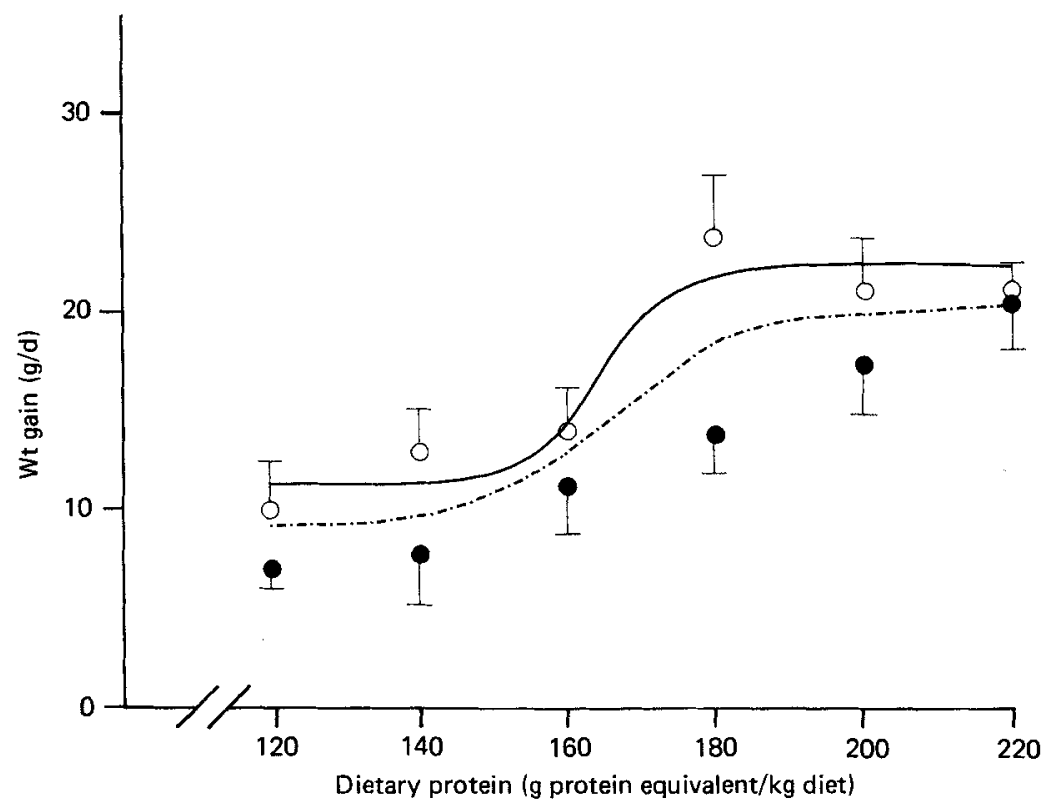

Fig. 1. Expt 2 (amino acid diets). Mean daily weight gain of male $(O)$ and female $(O)$ kittens. Vertical bars represent the standard error of the individual means. Curves represent calculated non-linear regressions $(\hat{\delta},-; \delta+q,-\cdot)$ whose parameters are given in Table 7 . For details of diets, see p. 502 and Table 2 .

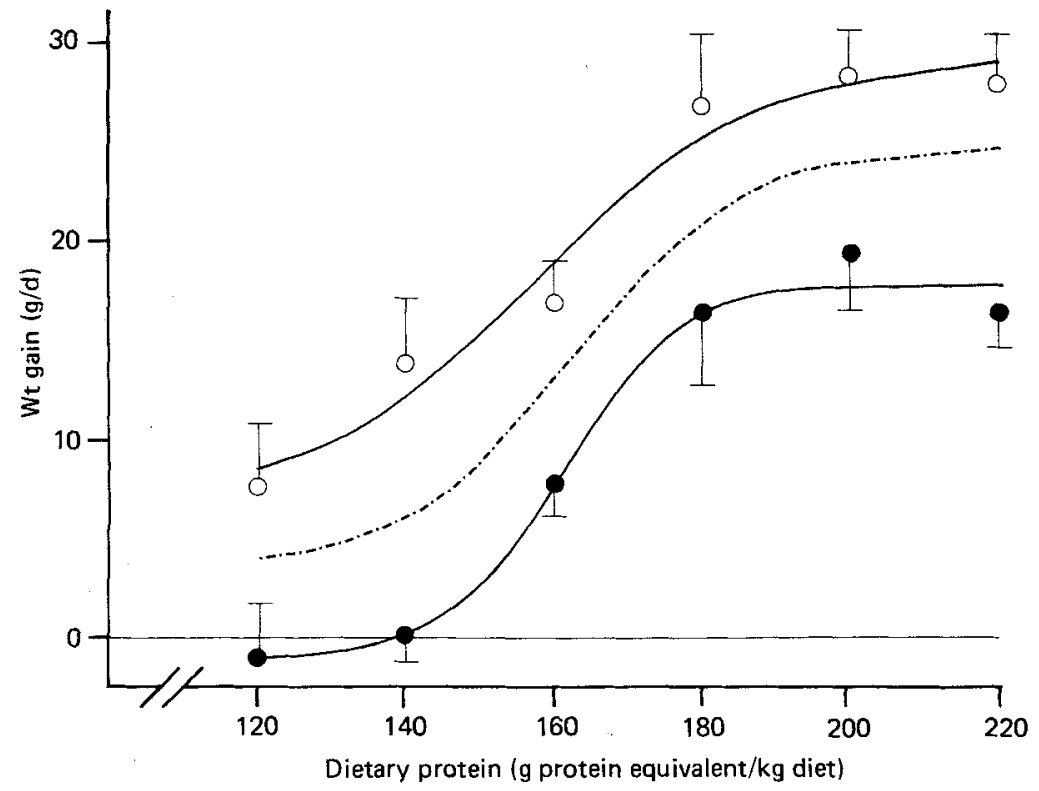

Fig. 2. Expt 3 (casein diets). Mean daily weight gain of male $(O)$ and female $(O)$ kittens. Vertical bars represent the standard error of the individual means. Curves represent calculated non-linear regressions $(\delta$ and $q$ individually, $-; \delta+q,-$.$) ) whose parameters are given in Table 7$. For details of diets, see p. 502 and Table 2 . 
Table 6. Effect of dietary protein level on nitrogen retention $(\mathrm{g} N / \mathrm{d})$ for three experiments*

(Values are means of average $\mathrm{N}$ retention of each animal over a $10 \mathrm{~d}$ period; no. of kittens given in parentheses)

\begin{tabular}{|c|c|c|c|c|c|c|c|c|c|}
\hline \multirow{2}{*}{$\begin{array}{c}\text { Expt no.... } \\
\text { Dietary } \\
\text { protein equivalent } \\
\text { (g/kg diet) }\end{array}$} & \multicolumn{3}{|c|}{1} & \multicolumn{3}{|c|}{2} & \multicolumn{3}{|c|}{3} \\
\hline & $\begin{array}{c}0 \\
(4)\end{array}$ & $\begin{array}{c}\text { } \\
(4)\end{array}$ & $\begin{array}{c}\sigma^{2}+9 \\
(8)\end{array}$ & $\begin{array}{c}\hat{0} \\
(6)\end{array}$ & $\begin{array}{c}q \\
(6)\end{array}$ & $\begin{array}{c}\delta+q \\
(12)\end{array}$ & $\begin{array}{l}0 \\
(6)\end{array}$ & $\begin{array}{c}q \\
(6)\end{array}$ & $\begin{array}{l}\hat{o}+q \\
(12)\end{array}$ \\
\hline 120 & - & - & - & $0 \cdot 37^{\mathrm{a}}$ & $0 \cdot 26^{\mathrm{a}}$ & $0 \cdot 32^{\mathrm{a}}$ & $0 \cdot 36^{\mathrm{a}}$ & $0 \cdot 13^{\mathrm{a}}$ & $0.25^{2}$ \\
\hline 140 & 0.39 & 0.28 & $0 \cdot 34^{\mathrm{a}}$ & $0.47^{\mathrm{a}}$ & $0.32^{\mathrm{a}}$ & $0.40^{\mathrm{ab}}$ & $0.55^{\mathrm{b}}$ & $0 \cdot 19^{a}$ & $0.37^{\mathrm{a}}$ \\
\hline 160 & 0.55 & $0 \cdot 34$ & $0.44^{\mathrm{ab}}$ & $0.52^{\mathrm{a}}$ & $0.39^{\mathrm{a}}$ & $0 \cdot 46^{\mathrm{b}}$ & $0.61^{\mathrm{b}}$ & $0.45^{\mathrm{b}}$ & $0.53^{\mathrm{h}}$ \\
\hline 180 & 0.58 & 0.47 & $0.52^{\mathrm{b}}$ & $0 \cdot 77^{\mathrm{b}}$ & $0.53^{b}$ & $0 \cdot 65^{\mathrm{c}}$ & $0.92^{\mathrm{c}}$ & $0 \cdot 61^{\mathrm{b}}$ & $0.77^{\mathrm{c}}$ \\
\hline 200 & 0.55 & 0.53 & $0.54^{\mathrm{b}}$ & $0.82^{\mathrm{b}}$ & $0.61^{\mathrm{b}}$ & $0.72^{\mathrm{c}}$ & $0.91^{\mathrm{c}}$ & $0.66^{\mathrm{b}}$ & $0.78^{\circ}$ \\
\hline 220 & - & - & - & $0-87^{\mathrm{b}}$ & $0.78^{c}$ & $0.83^{\mathrm{d}}$ & $1.03^{\mathrm{c}}$ & $0.67^{\mathrm{b}}$ & $0.85^{\circ}$ \\
\hline Pooled SE & $0 \cdot 10$ & 0.01 & 0.05 & 0.06 & 0.04 & 0.04 & 0.06 & 0.07 & 0.05 \\
\hline
\end{tabular}

a. b, c, d Means within a column with a different superscript letter were significantly different $(P<0.05)$.

* For details of experiments, see p. 502.

protein $/ \mathrm{kg}$ diet compared with the two lowest levels of dietary protein given in this experiment (120 and $140 \mathrm{~g} / \mathrm{kg}$ diet). Weight gains on the four highest levels of dietary protein were not significantly different for this group.

The sigmoidal model was fitted to weight gains of male and combined sexes in Expt 2, and male, female and combined sexes in Expt 3. The estimated parameters are found in Table 7 (p. 508) and the resulting regressions are shown in Figs. 1 and 2. The weight gain of one male kitten on the $220 \mathrm{~g} / \mathrm{kg}$ diet in Expt 3 was not included in calculating parameters for the non-linear regression. During the previous period this animal had been on the lowest protein diet $(120 \mathrm{~g} / \mathrm{kg})$ and had gained a total of $26 \mathrm{~g}$ during the $10 \mathrm{~d}$ period. When given the $220 \mathrm{~g} / \mathrm{kg}$ diet this kitten gained close to $500 \mathrm{~g}$ for the $10 \mathrm{~d}$ period, almost twice the gain of the other male kittens on this diet. This observation was rejected for the male weight gain and N-retention group for Expt 3, in accordance with the Anscombe \& Tukey (1963) rule for the Latin-square classification as explained in Snedecor \& Cochran (1967).

For all five regressions the $F$ values of the lack of fit mean square divided by the pure error mean square was less than one, indicating that the model provided an adequate description of the data. Tests of the overall regressions were significant $(P<0.05)$ in each case. The requirement, calculated as $95 \%$ of the upper asymptote, was $170 \mathrm{~g} / \mathrm{kg}$ and $190 \mathrm{~g} / \mathrm{kg}$ for male and combined sexes in Expt 2, and 200, 180 and $190 \mathrm{~g}$ protein $/ \mathrm{kg}$ diet for male, female and combined sexes in Expt 3.

Analysis of variance indicated a significant effect of dietary protein level on $\mathrm{N}$ retention for the female and combined sexes in Expt 1, and for the male, female and combined sexes in Expts 2 and 3 (Table 6). For the combined sexes in Expt 1, the range test indicated that $\mathrm{N}$ retention was significantly decreased on the $120 \mathrm{~g}$ protein $/ \mathrm{kg}$ diet compared with that on the 180 and $200 \mathrm{~g}$ protein $/ \mathrm{kg}$ diet. Male kittens in Expt 2 and the male and combined sexes in Expt 3 had a significantly higher $\mathbf{N}$ retention on the three highest levels of dietary protein $(180-220 \mathrm{~g} / \mathrm{kg})$ compared with the three lowest levels. For female kittens in Expt 3, $\mathrm{N}$ retention on the four highest levels of dietary protein $(160-220 \mathrm{~g} / \mathrm{kg})$ was significantly greater than retention on the two lowest levels. $\mathrm{N}$ retention for the female and combined sexes in Expt 2 was significantly greater at the highest level of dietary protein $(220 \mathrm{~g} / \mathrm{kg})$ compared with the lower five levels.

The sigmoidal model was fitted to $\mathrm{N}$ retention $v$. dietary crude protein level for the same 
Table 7. Parameters for the sigmoidal curves*

\begin{tabular}{|c|c|c|c|c|c|c|c|c|c|}
\hline \multirow{2}{*}{$\begin{array}{l}\text { Parameter... } \\
\text { Expt } \\
\text { no. } \dagger\end{array}$} & \multicolumn{2}{|c|}{ P1 } & \multicolumn{2}{|c|}{ P2 } & \multicolumn{2}{|c|}{ P3 } & \multicolumn{2}{|c|}{ P4 } & \multirow{2}{*}{$\begin{array}{l}\text { Calculated } \\
\text { requirement } \\
\text { (g/kg diet) }\end{array}$} \\
\hline & Mean & $\mathrm{SE}$ & Mean & $\mathrm{SE}$ & Mean & $\mathrm{SE}$ & Mean & $\mathrm{SE}$ & \\
\hline \multicolumn{10}{|c|}{ Wt gain } \\
\hline 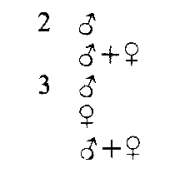 & $\begin{array}{r}11.55 \\
9.05 \\
7.23 \\
-0.95 \\
3.54\end{array}$ & $\begin{array}{l}0.64 \\
0.47 \\
2.26 \\
0.94 \\
0.93\end{array}$ & $\begin{array}{l}10 \cdot 42 \\
11 \cdot 17 \\
22 \cdot 13 \\
18 \cdot 82 \\
21 \cdot 11\end{array}$ & $\begin{array}{l}0.83 \\
0.69 \\
3.05 \\
1.32 \\
1.31\end{array}$ & $\begin{array}{l}49 \cdot 08 \\
18 \cdot 01 \\
11 \cdot 04 \\
22 \cdot 21 \\
14 \cdot 54\end{array}$ & $\begin{array}{l}0.53 \\
3 \cdot 5 \\
3 \cdot 35 \\
7 \cdot 16 \\
2 \cdot 52\end{array}$ & $\begin{array}{r}-300 \cdot 0 \\
-108 \cdot 86 \\
-70.03 \\
-137.99 \\
-89.79\end{array}$ & $\begin{array}{c}0 \\
20 \cdot 9 \\
20 \cdot 4 \\
44 \cdot 5 \\
15 \cdot 4\end{array}$ & $\begin{array}{l}170 \\
190 \\
200 \\
180 \\
190\end{array}$ \\
\hline \multicolumn{10}{|c|}{$\mathrm{N}$ retention } \\
\hline $\begin{array}{ll}2 & 0 \\
& 0 \\
3 & 0+q \\
3 & 0 \\
& + \\
& \\
& 0 \\
0 & +q\end{array}$ & $\begin{array}{l}0 \cdot 39 \\
0 \cdot 28 \\
0 \cdot 37 \\
0 \cdot 12 \\
0 \cdot 22\end{array}$ & $\begin{array}{l}0.03 \\
0.04 \\
0.05 \\
0.04 \\
0.04\end{array}$ & $\begin{array}{l}0.47 \\
0.61 \\
0.56 \\
0.55 \\
0.63\end{array}$ & $\begin{array}{l}0.04 \\
0.08 \\
0.07 \\
0.05 \\
0.05\end{array}$ & $\begin{array}{r}15 \cdot 03 \\
7.88 \\
12.83 \\
16.80 \\
11 \cdot 42\end{array}$ & $\begin{array}{l}4.05 \\
1.67 \\
3.81 \\
5.05 \\
2.15\end{array}$ & $\begin{array}{r}-89 \cdot 53 \\
-45 \cdot 14 \\
-81 \cdot 56 \\
-107 \cdot 26 \\
-72 \cdot 15\end{array}$ & $\begin{array}{r}24 \cdot 0 \\
9 \cdot 8 \\
23 \cdot 5 \\
31 \cdot 6 \\
13 \cdot 1\end{array}$ & $\begin{array}{l}190 \\
230 \\
190 \\
180 \\
190\end{array}$ \\
\hline
\end{tabular}

* The non-linear model used for these calculations was $y=\mathrm{P} 1+\mathrm{P} 2 /\left[1+\mathrm{e}^{(\mathrm{P} 8+\mathrm{P} 4 \cdot x)}\right]$, obtained from Robbins et al. (1979).

$\dagger$ For details of experiments, see p. 502.

$\ddagger$ Requirement calculated as levels of $x$ (dietary protein) at $95 \%$ of the upper asymptote $(\mathrm{P} 1+\mathrm{P} 2)$. For calculating parameters, dietary protein levels were expressed as $\mathrm{g} / \mathrm{g}$ diet, rather than as $\mathrm{g} / \mathrm{kg}$ diet, due to computer exponent limitations.

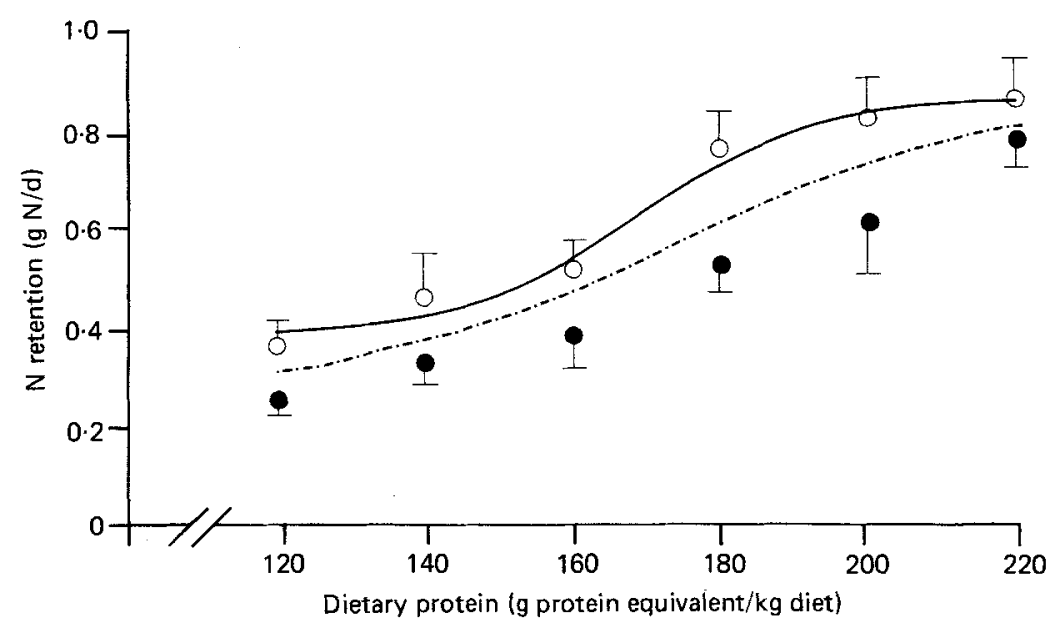

Fig. 3. Expt 2 (amino acid diets). Mean daily $N$ retention of male $(O)$ and female $(O)$ kittens. Vertical bars represent the standard error of the individual means. Curves represent calculated non-linear regressions $(\hat{\sigma},-\ldots ;+q,--)$ ) whose parameters are given in Table 7 . For details of diets, see p. 502 and Table 2 .

five groups which had been fitted for weight gain (Table 7 and Figs. 3 and 4). The $F$ values for lack of fit for each of the five regressions were less than one, and the regressions were significant. The calculated protein requirements ( $95 \%$ of the upper asymptote) for male and combined sexes in Expt 2 were 190 and $230 \mathrm{~g} / \mathrm{kg}$ respectively; and for male, female and combined sexes in Expt 3,190,180 and $190 \mathrm{~g} / \mathrm{kg}$ diet respectively (Table 7).

Plasma amino acid values for Expts 2 and 3 are given in Table 8. 


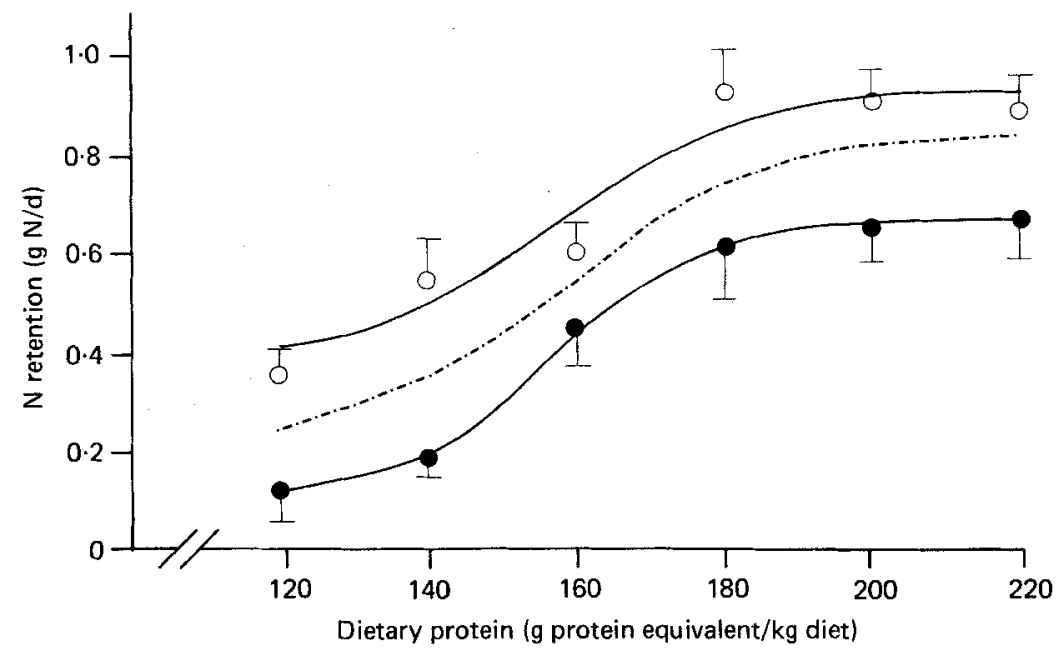

Fig. 4. Expt 3 (casein diets). Mean daily $\mathrm{N}$ retention of male $(O)$ and female $(0)$ kittens. Vertical bars represent the standard error of the individual means. Curves represent calculated non-linear regressions $(\hat{\partial}$ and $q$ individually, - $; \hat{\partial}+q,-\cdot)$ ) whose parameters are given in Table 7 . For details of diets, see p. 502 and Table 2.

Table 8. Plasma amino acid levels (umol/l)

\begin{tabular}{|c|c|c|c|c|c|c|}
\hline \multirow{3}{*}{$\begin{array}{l}\text { Expt no.*... } \\
\text { Dietary protein } \\
\text { equivalent }(\mathrm{g} / \mathrm{kg} \text { diet }) \ldots\end{array}$} & \multicolumn{2}{|c|}{2} & \multicolumn{4}{|c|}{3} \\
\hline & \multirow{2}{*}{$\begin{array}{c}120 \\
\text { (pooled } \\
\text { values) }\end{array}$} & \multirow{2}{*}{$\begin{array}{c}220 \\
\text { (pooled } \\
\text { values) }\end{array}$} & \multicolumn{2}{|c|}{120} & \multicolumn{2}{|c|}{220} \\
\hline & & & Mean & SE & Mean & $\mathrm{SE}$ \\
\hline Alanine & 493 & 534 & 482 & 6 & 659 & 77 \\
\hline Arginine & 201 & 384 & 166 & 16 & 181 & 20 \\
\hline Asparagine & 135 & 216 & 48 & 14 & 119 & 12 \\
\hline Aspartic acid & 40 & 51 & 28 & 2 & 44 & 3 \\
\hline Citrulline & 21 & 26 & 14 & 2 & 22 & 2 \\
\hline Cystathionine & 55 & 88 & 31 & 7 & 53 & 10 \\
\hline Glutamic acid & 79 & 85 & 77 & 16 & 90 & 7 \\
\hline Glutamine & 395 & 402 & 354 & 37 & 562 & 32 \\
\hline Glycine & 1644 & 1839 & 502 & 17 & 604 & 101 \\
\hline Histidine & 146 & 289 & 129 & 11 & 162 & 48 \\
\hline Hydroxyproline & 61 & 58 & 54 & 4 & 48 & 4 \\
\hline Isoleucine & 48 & 65 & 45 & 3 & 93 & 8 \\
\hline Leucine & 91 & 124 & 80 & 6 & 166 & 14 \\
\hline Lysine & 178 & 241 & 129 & 18 & 258 & 29 \\
\hline Methionine & 82 & 148 & 50 & 8 & 116 & 15 \\
\hline Ornithine & 134 & 119 & 49 & 5 & 56 & 30 \\
\hline Phenylalanine & 89 & 86 & 88 & 5 & 116 & 10 \\
\hline Proline & 129 & 144 & 117 & 12 & 292 & 46 \\
\hline Serine & 228 & 212 & 196 & 16 & 274 & 22 \\
\hline Threonine & 192 & 336 & 125 & 13 & 251 & 25 \\
\hline Tryptophan & 67 & 68 & 58 & 5 & 78 & 4 \\
\hline Tyrosine & 48 & 70 & 61 & 4 & 114 & 8 \\
\hline Valine & 92 & 167 & 131 & 11 & 280 & 25 \\
\hline
\end{tabular}

* For details of experiments, see p. 502. 


\section{DISCUSSION}

The majority of information on weight gain and $\mathrm{N}$ retention obtained in the present study indicates that the crude protein requirement of kittens on a purified diet providing $21 \mathrm{MJ} \mathrm{ME} / \mathrm{kg}$ diet is between 180 and $200 \mathrm{~g} / \mathrm{kg}$ diet. In Expt 2, female kittens, in contrast to male, appeared to reach maximum weight gain and $\mathrm{N}$ retention at $220 \mathrm{~g} / \mathrm{kg}$. This may indicate that either female kittens have a greater dietary protein requirement than male kittens or that utilization of an amino acid is less efficient in the female in comparison with the male kitten. The weight gain and $\mathrm{N}$ retention of the female kittens on Expt 3 do not support the former supposition; weight gain and $\mathrm{N}$ retention were maximized at the same dietary protein level for both sexes. On the other hand, the differences between female growth rates and $\mathrm{N}$ retention in Expt $2 v$. Expt 3 may be due to differences in the non-essential amino acid compositon of the diets. Previous work from this laboratory has indicated the importance of asparagine for maximal growth of kittens (E. M. Kamakawa, J. G. Morris and Q. R. Rogers, unpublished results); perhaps other non-essential amino acids are also necessary to support maximal growth, and this need may differ between the two sexes. Plasma amino acid values were not useful in determining the requirement. Most of the essential and non-essential amino acids in the dietary mixture increased in plasma with each increment of dietary protein; non-essential amino acids not in the dietary mixture remained relatively constant for all protein levels.

Previous investigators, utilizing diets based on unsupplemented natural proteins, have estimated the $\mathrm{N}$ requirement to be somewhat greater than our results suggest. Krehl \& Welt (1948) gave semi-purified diets modelled after the solids in cow's milk or bitch's milk to kittens and adult cats. Those diets modelled after cow's milk were found to be inadequate for kitten growth but sufficient to maintain adult cats. Bitch's milk, conversely, was able to maintain a moderate rate of growth in the kittens. This was most likely due to the higher protein content of the bitch's milk in comparison with the cow's milk $(25 \mathrm{v} .20 \%$ of total energy; Bernhart, 1961).

Dickinson \& Scott (1955) found that a diet in which protein provided $240 \mathrm{~g} / \mathrm{kg}$ dry diet, composed of herring and liver, was insufficient for growth of kittens. In a subsequent study (Dickinson \& Scott, 1956) these investigators examined growth of kittens at four levels of dietary protein: $230,300,370$ and $430 \mathrm{~g} / \mathrm{kg}$ dry diet. Protein in these diets was supplied by white fish, herring and liver. They concluded that growth was satisfactory only at the 370 or $430 \mathrm{~g} / \mathrm{kg}$ level of protein. The decrease in palatability of the lower-protein diets may have resulted in decreased food intake and thus confounded the results.

Casein has been utilized as the protein source in many $\mathrm{N}$-requirement studies. It has the advantage of being relatively constant in composition and readily available. A disadvantage of casein is that arginine and total sulphur amino acids become limiting for growing kittens when the diet contains less than $200-240 \mathrm{~g}$ casein crude protein $/ \mathrm{kg}$ diet.

Scott et al. (1957) found that $220 \mathrm{~g}$ casein $/ \mathrm{kg}$ was insufficient to maintain growth in kittens but that $330 \mathrm{~g}$ casein $/ \mathrm{kg}$ was adequate. Likewise, Miller $\&$ Allison (1958) found that kitten's growth rate was highest on a diet in which casein composed $250-300 \mathrm{~g} / \mathrm{kg}$ of a dry diet with approximately $290 \mathrm{~g}$ fat $/ \mathrm{kg}$ diet.

More recently, Jansen et al. (1975) examined growth and carcass $\mathrm{N}$ content on four different levels of dietary protein as casein: $260,310,360$ and $400 \mathrm{~g} / \mathrm{kg}$ dry diet. Neither weight gain nor carcass $\mathrm{N}$ composition differed significantly with dietary protein content, but weight gain did plateau at $360-400 \mathrm{~g}$ protein $/ \mathrm{kg}$ diet. These workers concluded that $350 \mathrm{~g}$ protein $/ \mathrm{kg}$ was a reasonable requirement to provide for maximal weight gain of kittens.

The requirement range we propose $(180-200 \mathrm{~g}$ protein $/ \mathrm{kg}$ diet) is higher than that estimated by Anderson et al. (1980) utilizing crystalline amino acid diets. In one of their 
experiments, three levels of dietary protein equivalent were tested: 134,158 and $182 \mathrm{~g} / \mathrm{kg}$ diet. These levels were formulated by keeping the essential amino acids constant and increasing the proportion of non-essential amino acids. There was no significant change in weight gain, weight gain: feed value, weight gain: $\mathrm{N}$ intake value or ammonia- $\mathrm{N}$ excretion between treatments; in addition, weight gains were poor $(9-10 \mathrm{~g} / \mathrm{d})$ on all diets. In another experiment, the $158 \mathrm{~g}$ protein $/ \mathrm{kg}$ diet was compared with a commercial cat chow; weight gain over a $32 \mathrm{~d}$ period was somewhat under $20 \mathrm{~g} / \mathrm{d}$ on the $157.5 \mathrm{~g}$ protein equivalent $/ \mathrm{kg}$ purified diet. The estimate by Anderson et al. (1980) of the requirement is based on the equivalent response to the commercial cat chow.

The kitten's protein requirement for growth is greater than that of many other mammals. Direct comparison of protein requirements between species is complicated by several factors, i.e. the energy concentration in the diet, the amino acid composition of the diet in relation to the essential amino acid requirements of the species, the digestibility of the dietary protein and the age of the animals used in the study. In addition, requirements of several species (e.g. pig, mink and fox) are typically determined with mixed-protein diets, involving vegetable or meat by-product proteins, and cannot be considered indicative of the minimal amount of $\mathrm{N}$ required to attain maximal $\mathrm{N}$ retention by these species. To avoid some of these difficulties, only requirements determined with either high quality, semi-purified protein sources or crystalline amino acids were examined for comparison.

For maximal weight gain in growing rats given lactalbumen- or casein-based diets, crude protein levels of 115-120 g/ $\mathrm{kg}$ diet are required in diets containing 120-150 g fat $/ \mathrm{kg}$ (Breuer et al. 1964; Bunce \& King, 1969; Burns et al. 1982). The growing mouse has a similar requirement of $125 \mathrm{~g}$ protein $/ \mathrm{kg}$ diet, determined with a casein plus amino acid diet with $100 \mathrm{~g}$ fat/kg diet (John \& Bell, 1976).

The dog has been shown to have a somewhat higher $\mathrm{N}$ requirement than either the rat or mouse. Milner (1981) was able to attain maximal weight gain on diets providing $140 \mathrm{~g}$ protein equivalent $/ \mathrm{kg}$, composed of crystalline L-amino acids with $50 \mathrm{~g}$ fat $/ \mathrm{kg}$. In the same study, $\mathrm{N}$ balance increased with each increment of dietary protein. Using lactalbumen-based diets with $120 \mathrm{~g}$ fat $/ \mathrm{kg}$, Burns et al. (1982) found no change in weight gain of young beagles on diets with between 150 and $200 \mathrm{~g}$ protein $/ \mathrm{kg}$ diet.

The requirement range as determined in the present study is based on diets containing $250 \mathrm{~g}$ fat $/ \mathrm{kg}$ diet and having an apparent crude protein digestibility of 0.90 and 0.95 for the amino acid and casein diets respectively (determined on $200 \mathrm{~g}$ protein $/ \mathrm{kg}$ diet). Commercial cat foods are less digestible, with apparent crude protein digestibility for semi-moist and dry foods of 0.75 and for canned food of 0.80 (Kendall et al. 1982). Application of the requirement determined in the present study to commercial foods must take into account this lower digestibility and also the differences in energy density.

Burger et al. (1985) suggest that the minimal protein requirement of the adult cat is $125 \mathrm{~g} / \mathrm{kg}$ diet. This indicates that approximately 0.66 of the kitten's requirement for $\mathrm{N}$ is utilized for maintenance. For omnivorous mammals, the proportion of the $\mathrm{N}$ requirement needed for maintenance is much lower: 0.35 for the rat and 0.33 for the dog. The kitten's high $\mathrm{N}$ requirement for maintenance is consistent with the finding that unlike omnivorous mammals, such as the rat (Schimke, 1962; Anderson et al. 1968; Das \& Waterlow, 1974), the activities of enzymes involved in $\mathrm{N}$ catabolism in the kitten are unaffected by dietary protein level (Rogers et al. 1977). In omnivorous mammals, the ability to adapt to variations in dietary protein intake with changes in $\mathrm{N}$ catabolic enzyme activity is beneficial in that it contributes to the conservation of amino acids on low-protein intakes and, conversely, provides a mechanism to catabolize excess amino acids on a high-protein regimen. Although the relative affinities for amino acids by the $\mathrm{N}$ catabolic enzymes and the tRNA synthetases are unknown in the kitten, this inability to adapt enzymically to variations in dietary protein content may account in part for the kitten's high $\mathrm{N}$ requirement for maintenance. 
The authors wish to thank Linda Buria and Arthur Aguirre for their assistance during these experiments, and Ajinomoto Inc., USA, for the gift of part of the crystalline amino acids. This research was supported in part by a grant from the Pet Food Institute, Washington, DC.

\section{REFERENCES}

Anderson, H. L., Benevenga, N. J. \& Harper, H. A. (1968). American Journal of Physiology 214, $1008-1013$.

Anderson, P. A., Baker, D. H., Sherry, P. A. \& Corbin, J. E. (1980). American Journal of Veterinary Research 41, 1646-1649.

Anscombe, F. J. \& Tukey, J. W. (1963). Technometrics 5, 141-160.

Association of Official Agricultural Chemists. (1975). Official Methods of Analysis, 12th ed. Washington, D.C. Association of Official Agricultural Chemists.

Bernhart, F. W. (1961). Nature 191, 358-360.

Breuer, L. H. Jr, Pond, W. G., Warner, R. G. \& Loosli, J. K. (1964). Journal of Nutrition 82, 499-506.

Bunce, G. E. \& King, K. W. (1969). Journal of Nutrition 98, 168-176.

Burger, I. H., Blaza, S. E., Kendall, P. J. \& Smith, P. M. (1985). Feline Practice (In the Press).

Burns, R. A., LeFaivre, M. H. \& Milner, J. A. (1982). Journal of Nutrition 112, 1843-1853.

Cochran, W. G. \& Cox, G. M. (1957). Experimental Designs, 2nd ed. New York: Wiley.

Das, T. K. \& Waterlow, J. C. (1974). British Journal of Nutrition 32, 353-373.

Dickinson, C. D. \& Scott, P. P. (1955). Journal of Physiology 129, 78p.

Dickinson, C. D. \& Scott, P. P. (1956). British Journal of Nutrition 10, 311-316.

Draper, N. R. \& Smith, H. (1981). Applied Regression Analysis, 2nd ed. New York: Wiley.

Jansen, G. R., Deuth, M. A., Ward, G. M. \& Johnson, D. E. (1975). Nutrition Reports International 11, 525-536. John, A.-M. \& Bell, J. M. (1976). Journal of Nutrition 106, 1361-1367.

Kendall, P. T., Smith, P. M. \& Holme, D. W. (1982). Journal of Small Animal Practice 23, 517-613.

Krehl, W. A. \& Welt, I. D. (1948). Federation of American Societies for Experimental Biology Proceedings 7, 166. Miller, S. A. \& Allison, J. B. (1958). Journal of Nutrition 64, 493-501.

Milner, J. A. (1981). Journal of Nutrition 111, 40-45.

National Research Council. (1978). Nutrient Requirements of Domestic Animals no. 13, Nutrient Requirements of Cats. Washington, D.C.: National Academy of Science/National Research Council.

Ralston, M. (1981). In BMDP Statistical Software 1981, Sect. 14.2 [W. J. Dixon, chief editor]. Berkeley: University of California Press.

Robbins, K. R., Norton, H. W. \& Baker, D. H. (1979). Journal of Nutrition 109, 1710-1714.

Rogers, Q. R., Chen, D. M.-Y. \& Harper, A. E. (1970). Society for Experimental Biology and Medicine Proceedings 134, 517-522.

Rogers, Q. R. \& Morris, J. G. (1982). Journal of Small Animal Practice 23, 521-532.

Rogers, Q. R., Morris, J. G. \& Freedland,' R. A. (1977). Enzyme 22, 348-356.

Schimke, R. J. (1962). Journal of Biological Chemistry 237, 459-468.

Scott, P. P., Carvalho da Silva, A. \& Lloyd-Jacob, M. A. (1957). In UFAW Handbook on the Care and Management of Laboratory Animals, 2nd ed., p. 479 [A. Worden and A. Lane Petter, editors]. London: Universities' Federation for Animal Welfare.

Smalley, K. A., Rogers, Q. R. \& Morris, J. G. (1983). British Journal of Nutrition 49, 411-417.

Snedecor, G. W. \& Cochran, W. G. (1967). Statistical Methods, 6th ed. Ames: Iowa State University Press.

Steel, R. G. D. \& Torrie, J. H. (1980). Principles and Procedures of Statistics, 2nd ed. New York: McGraw-Hill Book Co. 